\title{
Research on train operation stability by the installation of platform doors
}

\author{
S. Adachi ${ }^{1,2}$, N. Harata ${ }^{1}$, Y. Takatori ${ }^{2}$ \& M. Koresawa ${ }^{2}$ \\ ${ }^{1}$ The University of Tokyo, Japan \\ ${ }^{2}$ Tokyo Metro Co., Ltd., Japan
}

\begin{abstract}
In order to improve safety, platform doors have been installed in some train and subway stations in the Tokyo metropolitan area of Japan. The number of accidents (such as passengers falling from platforms, or coming into contact with moving trains) has decreased. On the other hand, scheduled dwell times have had to be increased to allow for the extra time needed for platform doors to open and close. As such, travel times are longer after the installation of platform doors than before. However, an overall improvement in the stability of train operations has been observed during rush hour. This paper presents an analysis of such phenomenon and valuates the train operation stability.

Keywords: train operation stability, platform doors, train delay, dwell time, confirmation time, train traffic record data.
\end{abstract}

\section{Introduction}

In recent years, there have been increasing discussions about the installation of platform doors in train and subway stations, in order to improve safety. In 2011, the Ministry of Land, Infrastructure, Transport and Tourism and railway companies established a meeting to consider the promotion of installation of platform doors. In this meeting, it was decided that stations which are used by more than $1,000,000$ passengers per day should be prioritized for installation of platform doors. Railway companies have subsequently begun the process with serious effort. On the other hand, scheduled dwell times have had to be increased to allow for the extra time needed for platform doors and gap fillers (Figure 1) to open and close. As such, travel times have become longer after the installation of platform doors. During morning rush hour especially, intervals between preceding 
train departure times and subsequent train arrival times is reduced, thus increasing the risk of train delay propagation. However, an overall improvement in the stability of train operations has been observed during rush hour. Due to the fact that some passengers walk at the edge of platforms, it is often difficult for station staff to confirm safety along the sides of train cars. This is especially true before train departures. The installation of platform doors prevents passengers from approaching the sides of cars too closely, and obstacle sensors attached to the platform doors work to confirm safety in the direct vicinity of trains in stations. In this sense, the time and required for station staff to make visual safety checks is alleviated by the function of platform doors. Furthermore, one-man operation could be adopted if platform doors are installed. Another positive impact on train operation is that train drivers can confirm safety using car-mounted cameras without the need for safety confirmation from station staff. It is therefore recognized that the installation of platform doors has a net positive effect on train transportation stability. Train operation stability has been widely discussed. The discussion could be classified roughly into three categories. One is to improve stability by means of improving the train schedules themselves [1-4]; another is by improving station staff operation $[5,6]$; the other is by improving facilities and train operating systems $[5,6]$. But thus far, the benefits of platform doors on train operation stability have not been widely discussed.

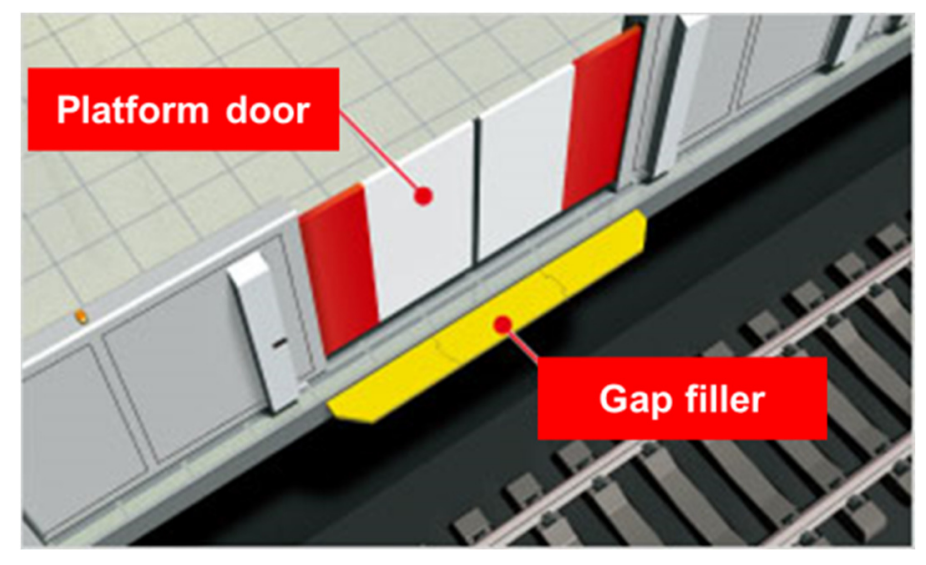

Figure 1: Platform door and gap filler.

\section{Structure of train timetables}

If platform doors are installed, scheduled dwell times have to be increased to allow for the extra time needed for platform doors and gap fillers to open and close. This is because sensors on cars and the ground have to make contact with each other to confirm car-stop position and activate the opening and closing of doors. 
This situation is indicated in Figure 2, where " $a$ " is defined as the dwell time of Train 1 at station B. " $b$ " is defined as the minimum time between the preceding train's departure time and the subsequent train's arrival time at station B; " $b$ " is decided by the signalling system; " $c$ " is defined as buffer time; " $d$ " is defined as the train interval which is the sum of " $a$ " " $b$ " and " $c$ "; " $e$ " is defined as running time of subsequent Train 3. For example, note in Figure 2, that without platform doors, " $a$ " is 40 seconds, " $b$ " is 60 seconds and " $c$ " is 20 seconds, whereas the installation of platform doors would necessitate " $a$ " being increased by 5 seconds and " $c$ " shortened to 15 seconds. In such a case, if Train 1 exceeds the planned dwell time, the risk of " $e$ " increases.

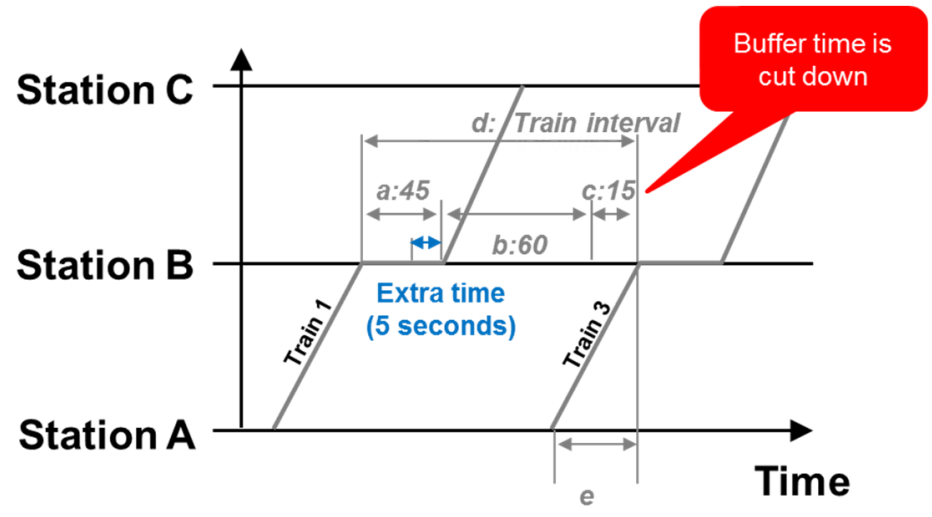

Figure 2: Structure of train timetable.

\section{An outline of time to confirm safety}

\subsection{A time to confirm safety during morning rush hour}

A structure of dwell time is indicated in Figure 3. If platform doors are installed or one-man operation is adopted due to the installation of platform doors, the time to confirm safety will change. Train operation can be labelled as two-man operation without platform doors; two-man operation with platform doors; oneman operation with platform doors.

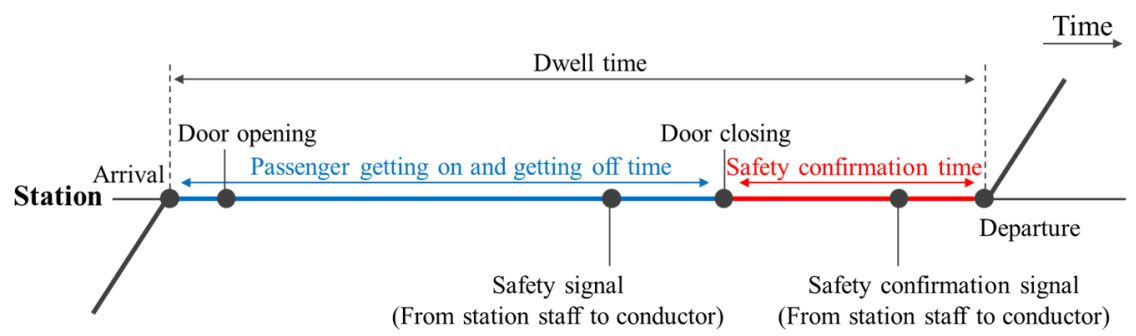

Figure 3: $\quad$ Structure of dwell time. 
We investigated details of dwell times for each scenario by on-sight inspections on Tokyo Metro lines (Table 1). In two-man operation without platform doors, we investigated 485 trains at some congested stations (station A to station C). Under these circumstances, there was a lot of passenger congestion impeding car doors closure and safety confirmation on the platforms and the time to confirm safety was increased. In two-man operation with platform doors, we investigated 457 trains at some congested stations (station D to station F). The safety confirmation times were shorter than two-man operation without platform doors. In one-man operation with platform doors, we investigated 304 trains at some congested stations (station $\mathrm{G}$ to station I). The time to confirm safety was shorter still.

Table 1: Investigation of time to confirm safety.

\begin{tabular}{|l|c|c|c|c|}
\hline \multicolumn{1}{|c|}{ Type of operation } & $\begin{array}{c}\text { Station } \\
\text { name }\end{array}$ & $\begin{array}{c}\text { Number of } \\
\text { trains }\end{array}$ & $\begin{array}{c}\text { Average time to } \\
\text { confirm safety }\end{array}$ & $\begin{array}{c}\text { Standard } \\
\text { deviation }\end{array}$ \\
\hline \multirow{2}{*}{$\begin{array}{l}\text { Two-man operation } \\
\text { without platform } \\
\text { doors }\end{array}$} & $\mathrm{A}$ & 176 & $16^{\prime \prime}$ & $2^{\prime \prime}$ \\
\cline { 2 - 5 } & $\mathrm{B}$ & 152 & $18^{\prime \prime}$ & $3^{\prime \prime}$ \\
\cline { 2 - 5 } & $\mathrm{C}$ & 157 & $16^{\prime \prime}$ & $4^{\prime \prime}$ \\
\hline \multirow{2}{*}{$\begin{array}{c}\text { Two-man operation } \\
\text { with platform doors }\end{array}$} & $\mathrm{D}$ & 137 & $13^{\prime \prime}$ & $2^{\prime \prime}$ \\
\cline { 2 - 5 } & $\mathrm{E}$ & 159 & $13^{\prime \prime}$ & $2^{\prime \prime}$ \\
\hline \multirow{2}{*}{$\begin{array}{l}\text { One-man operation } \\
\text { with platform doors }\end{array}$} & $\mathrm{F}$ & 161 & $15^{\prime \prime}$ & $2^{\prime \prime}$ \\
\cline { 2 - 5 } & $\mathrm{G}$ & 128 & $9^{\prime \prime}$ & $2^{\prime \prime}$ \\
\cline { 2 - 5 } & $\mathrm{H}$ & 126 & $10^{\prime \prime}$ & $2^{\prime \prime}$ \\
\hline
\end{tabular}

\subsection{Alteration of time to confirm safety due to individual characteristics of stations}

Alteration of time to confirm safety was identified, but we have to analyse the alteration in consideration of individual characteristics of stations, including passenger congestion and how to confirm safety. We interviewed station staff members and conductors. The result is expressed in Table 2 . The following 4 cases were categorized by method of safety confirmation and passenger congestion impeding car door closure and safety confirmation. The dwell time stability is valuated on a scale of blue to red. Blue indicates the best stability, and red indicates the worst. If the valuation is between blue and red, the colour is green or yellow.

Case 1 is a general situation in which there is no passenger congestion impeding visual inspection on the platform, and one station staff member can confirm safety along cars. In two-man operation, the valuation is green. In one-man operation, the valuation is blue because confirmation time is shorter than twoman operation. Case 2 is no passenger congestion impeding visual inspection on the platform, but some station staff members have to relay signals confirming safety along the sides of cars, or one station staff member has to take a long time to confirm safety because of a curved-shape platform. In a two-man operation without platform doors, the valuation is yellow because confirmation time is greater than in Case 1. In two-man operation with platform doors, the valuation 
is green. In one-man operation with platform doors, the valuation is blue. In Case 3 , passenger congestion impedes visual inspection on the platform, and station staff don't need to relay safety signals. In two-man operation without platform doors, the valuation is red because confirmation time is greater than in other types of train operation. In two-man operation with platform doors, the valuation is yellow, as in case 2 of two-man operation without platform doors. In one-man operation with platform doors, the valuation is green. The confirmation time by train drivers gets worse as passenger congestion increases. Case 4 is passenger congestion impeding visual inspection on the platform, and station staff have to relay safety signals along the sides of cars because of a curved-shape platform. In two-man operation without platform doors, the valuation is red. In two-man operation with platform doors, the valuation is also red. In one-man operation with platform doors, the valuation is green.

Table 2: Categorization of dwell time stability regarding individual characteristics of stations.

\begin{tabular}{|c|c|c|c|c|c|}
\hline \multirow[b]{2}{*}{ Case } & \multicolumn{2}{|c|}{$\begin{array}{c}\text { Characteristics of station } \\
\text { situation }\end{array}$} & \multicolumn{3}{|c|}{ Type of train operation } \\
\hline & $\begin{array}{l}\text { Method to } \\
\text { confirm } \\
\text { safety }\end{array}$ & $\begin{array}{l}\text { Passenger } \\
\text { congestion } \\
\text { impeding } \\
\text { visual } \\
\text { inspection }\end{array}$ & $\begin{array}{l}\text { Two-man } \\
\text { operation } \\
\text { without } \\
\text { platform } \\
\text { doors }\end{array}$ & $\begin{array}{l}\text { Two-man } \\
\text { operation } \\
\text { with } \\
\text { platform } \\
\text { doors }\end{array}$ & $\begin{array}{l}\text { One-man } \\
\text { operation } \\
\text { with } \\
\text { platform } \\
\text { doors }\end{array}$ \\
\hline 1 & No relay & $\begin{array}{l}\text { Without } \\
\text { passenger } \\
\text { congestion }\end{array}$ & & & \\
\hline 2 & $\begin{array}{l}\text { Relay or no } \\
\text { relay } \\
\text { taking a } \\
\text { long time }\end{array}$ & $\begin{array}{l}\text { Without } \\
\text { passenger } \\
\text { congestion }\end{array}$ & & & \\
\hline 3 & No relay & $\begin{array}{c}\text { With } \\
\text { passenger } \\
\text { congestion }\end{array}$ & & & \\
\hline 4 & $\begin{array}{l}\text { Relay or no } \\
\text { relay } \\
\text { taking a } \\
\text { long time }\end{array}$ & $\begin{array}{c}\text { With } \\
\text { passenger } \\
\text { congestion }\end{array}$ & & & \\
\hline
\end{tabular}

Stability

Non stability 


\section{Sorting of train operation data and elements}

\subsection{Utilizing the train traffic record data}

In recent years, we can get train traffic record data, which are collected from track occupation status. Train traffic record data contain actual arrival and departure times of all trains, every day. These data are very useful to understand train operation.

\subsection{Sorting of various train operation elements}

In our analysis, we focused on two Tokyo Metro lines. One was the Yurakucho Line, which can be analysed comparing two-man operation without platform doors and two-man operation with platform doors. The other was the Marunouchi Line, which can be analysed comparing two-man operation with platform doors and one-man operation with platform doors. The train traffic record data were chosen in June or November, excluding days when any trouble caused delays of 3 or more minutes and long dwell time to adjust train interval. The stations along Tokyo Metro's Yurakucho Line had platform doors installed between 2010 and 2012, so we compared November 2009 and November 2012. Tokyo Metro's Marunouchi Line adopted a one-man operation in June 2009, so we compared June 2008 and June 2009.

\subsection{Amount of dwell time change}

The stations are categorized as follows (see Tables 3 and 4). As indicated, the dwell times at stations along the Yurakucho Line require an additional 5 seconds for platform doors to open and close, and an additional 8 seconds for both platform doors and gap fillers to open and close.

Table 3: Amount of average dwell time change on the Yurakucho Line.

\begin{tabular}{|c|l|r|c|c|c|}
\hline Case & Station name & $\begin{array}{c}\text { Average } \\
\text { dwell time } \\
\text { in Nov. } \\
2009\end{array}$ & $\begin{array}{c}\text { Average } \\
\text { dwell time } \\
\text { in Nov. } \\
2012\end{array}$ & $\begin{array}{c}\text { Additional time } \\
\text { (platform doors } \\
\text { and gap fillers } \\
\text { open and close } \\
\text { time) }\end{array}$ & $\begin{array}{c}\text { Amount of } \\
\text { average } \\
\text { dwell time } \\
\text { change }\end{array}$ \\
\hline \multirow{4}{*}{1} & Kojimachi & $35^{\prime \prime}\left(5^{\prime \prime}\right)$ & $39^{\prime \prime}\left(4^{\prime \prime}\right)$ & $+5^{\prime \prime}$ & $-1^{\prime \prime}$ \\
& Sakuradamon & $29^{\prime \prime}\left(5^{\prime \prime}\right)$ & $37^{\prime \prime}\left(5^{\prime \prime}\right)$ & $+8^{\prime \prime}$ & $\pm 0^{\prime \prime}$ \\
\hline \multirow{3}{*}{2} & Gokokuji & $42^{\prime \prime}\left(10^{\prime \prime}\right)$ & $44^{\prime \prime}\left(8^{\prime \prime}\right)$ & $+8^{\prime \prime}$ & $-6^{\prime \prime}$ \\
& Edogawabashi & $43^{\prime \prime}\left(9^{\prime \prime}\right)$ & $46^{\prime \prime}\left(8^{\prime \prime}\right)$ & $+8^{\prime \prime}$ & $-5^{\prime \prime}$ \\
& Nagatacho & $49^{\prime \prime}\left(6^{\prime \prime}\right)$ & $52^{\prime \prime}\left(6^{\prime \prime}\right)$ & $+8^{\prime \prime}$ & $-5^{\prime \prime}$ \\
\hline \multirow{3}{*}{4} & Iidabashi & $47^{\prime \prime}\left(8^{\prime \prime}\right)$ & $51^{\prime \prime}\left(8^{\prime \prime}\right)$ & $+5^{\prime \prime}$ & $-1^{\prime \prime}$ \\
& Ichigaya & $44^{\prime \prime}\left(8^{\prime \prime}\right)$ & $48^{\prime \prime}\left(7^{\prime \prime}\right)$ & $+5^{\prime \prime}$ & $-1^{\prime \prime}$ \\
& Yurakucho & $46^{\prime \prime}\left(8^{\prime \prime}\right)$ & $49^{\prime \prime}\left(7^{\prime \prime}\right)$ & $+5^{\prime \prime}$ & $-2^{\prime \prime}$ \\
\hline
\end{tabular}

NB: (x) indicates standard deviation.

Number of observations: 216 in 2009, 144 in 2012. 
Table 4: Amount of average dwell time change on the Marunouchi Line.

\begin{tabular}{|c|l|c|c|c|}
\hline Case & Station name & $\begin{array}{c}\text { Average dwell } \\
\text { time in Jun. } \\
2008\end{array}$ & $\begin{array}{c}\text { Average dwell } \\
\text { time in Jun. } \\
2009\end{array}$ & $\begin{array}{c}\text { Amount of } \\
\text { average dwell } \\
\text { time change }\end{array}$ \\
\hline 1 & Shin-otsuka & $35^{\prime \prime}\left(7^{\prime \prime}\right)$ & $33^{\prime \prime}\left(6^{\prime \prime}\right)$ & $-2^{\prime \prime}$ \\
$47^{\prime \prime}\left(6^{\prime \prime}\right)$ & $46^{\prime \prime}\left(8^{\prime \prime}\right)$ & $-1^{\prime \prime}$ \\
\hline 2 & Kwajicho & $46^{\prime \prime}\left(7^{\prime \prime}\right)$ & $41^{\prime \prime}\left(7^{\prime \prime}\right)$ & $-5^{\prime \prime}$ \\
\hline 3 & Korakuen & $36^{\prime \prime}\left(6^{\prime \prime}\right)$ & $34^{\prime \prime}\left(8^{\prime \prime}\right)$ & $-2^{\prime \prime}$ \\
\hline 4 & Hongogadani & $49^{\prime \prime}\left(8^{\prime \prime}\right)$ & $46^{\prime \prime}\left(8^{\prime \prime}\right)$ & $-3^{\prime \prime}$ \\
\hline
\end{tabular}

NB: (x) indicates standard deviation.

Number of observations: 480 in 2008, 256 in 2009.

\section{Analysis of train operation stability}

\subsection{Analysis of train operation stability on the Yurakucho Line}

The Yurakucho Line operates 24 trains during the morning 1-hour peak, and trains operate as through-service with the Tobu and Seibu lines. Trains which operate as through with the Tobu Line are more congested than with the Seibu Line, and without through-service operation. The operation outline of Yurakucho Line is indicated in Figure 4. We focussed on individual characteristics of stations, as well as the congestion characteristics of through-service trains, to make our regression analysis. We decided that the explained variable would be the amount of average dwell time change, and the explanatory variables would be individual station characteristics and through-service operation type (such as through with the Tobu Line, or through with the Seibu Line, or no through-service operation).

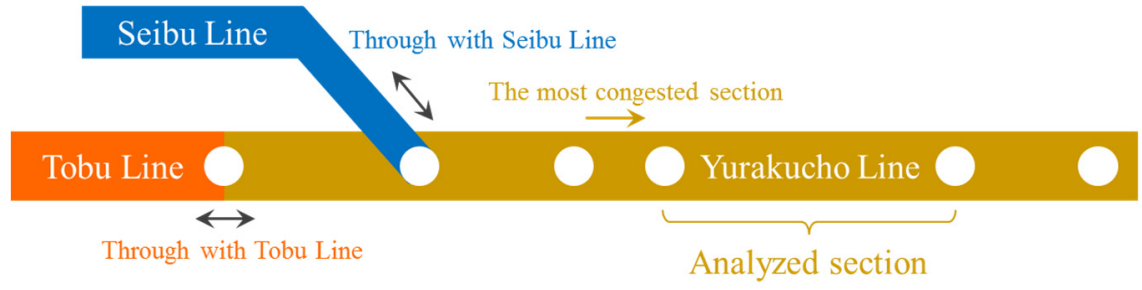

Figure 4: Operation outline of Yurakucho Line.

The model is expressed in the following Eq. (1).

$$
\Delta D=\alpha+\beta_{1} \text { Case } 2+\beta_{2} \text { Case } 4+\beta_{3} S B+\beta_{4} T B
$$


8 Computers in Railways XV: Railway Engineering Design and Operation

Legend:

$S B$ : Dummy variable of through-service operation with Seibu Line;

$T B$ : Dummy variable of through-service operation with Tobu Line;

$\triangle D$ : Amount of average dwell time change;

$\alpha$ : Constant term;

Case 2: Dummy variable of case 2;

Case 4: Dummy variable of case 4.

Table 5: Results of Yurakucho Line analysis.

\begin{tabular}{|c|r|r|r|}
\hline Variable & \multicolumn{1}{|c|}{ Coefficient } & \multicolumn{1}{c|}{ t-value } & \multicolumn{1}{c|}{$\mathrm{p}$-value } \\
\hline Case2 & -4.54597 & -5.65112 & $5.87 \mathrm{E}-8$ \\
\hline Case4 & -0.55458 & -0.6894 & 0.491429 \\
\hline$S B$ & -0.12801 & -0.17681 & 0.859848 \\
\hline$T B$ & -1.95295 & -2.36921 & 0.018845 \\
\hline
\end{tabular}

Number of observations: 192 (24 trains x 8 stations) $\mathrm{R}^{2}$ : 0.460069.

According to the results in Table 5, the coefficient of Case 2 becomes largest and statistically significant. This has a positive impact on improvement of dwell time. The coefficient of TB is also statistically significant. This also has a positive impact. Therefore, when platform doors are installed, under two-man operation, it is apparent that relay and excessive dwell time is alleviated for Case 2 and congested trains.

\subsection{Analysis of train operation stability on the Marunouchi Line}

Marunouchi Line operates 32 trains during morning 1-hour peak (8:00-9:00). The line does not operate through-service, so the congestion depends on the time zone. The congestion increases toward the middle of peak hour, then decreases toward the end of the peak hour. Considering this, we decided that the explained variable would be the amount of average dwell time change, and the explanatory variables would be individual station characteristics and time zone divided into 10-minute intervals. The model is expressed in the following Eq. (2).

$$
\Delta D=\alpha+\beta_{1} \text { Case } 2+\beta_{2} \text { Case } 3+\beta_{3} \text { Case } 4+\beta_{4} T_{10-20}+\beta_{5} T_{20-30}+\beta_{6} T_{30-40}+\beta_{7} T_{40-50}+\beta_{8} T_{50-00}
$$

Legend:

$\Delta D$ : Amount of average dwell time change;

$\alpha$ : Constant term;

Case 2: Dummy variable of case 2;

Case 3: Dummy variable of case 3;

Case4: Dummy variable of case 4;

$T_{10-20}$ : Dummy variable of departure time (8:10-8:20); 
$T_{20-30}$ : Dummy variable of departure time (8:20-8:30);

$T_{30-40}$ : Dummy variable of departure time (8:30-8:40);

$T_{40-50}$ : Dummy variable of departure time $(8: 40-8: 50)$;

$T_{50-00}$ : Dummy variable of departure time (8:50-9:00).

Table 6: Results of Marunouchi Line analysis.

\begin{tabular}{|c|r|r|r|}
\hline Variable & Coefficient & t-value & \multicolumn{1}{c|}{ p-value } \\
\hline Case2 & -1.72106 & -3.2753 & 0.001262 \\
\hline Case3 & -1.47444 & -2.29107 & 0.023099 \\
\hline Case4 & -5.93363 & -9.21999 & $7.13 \mathrm{E}-17$ \\
\hline$T_{10-20}$ & -0.74636 & -1.01571 & 0.311108 \\
\hline$T_{20-30}$ & -1.52371 & -2.1748 & 0.030918 \\
\hline$T_{30-40}$ & 0.463598 & 0.630902 & 0.528892 \\
\hline$T_{40-50}$ & 1.286733 & 1.751092 & 0.081606 \\
\hline$T_{50-00}$ & 0.314233 & 0.427634 & 0.66942 \\
\hline
\end{tabular}

Number of observations: 192 (32 trains x 6 stations) R $^{2}: 0.601378$.

According to the results in Table 6, all coefficients of case dummies are statistically significant - especially the coefficient of Case 4 with the largest size of -5.93363. So, that means: platform doors improved safety confirmation on congested platforms and led to better overall efficiency. Furthermore, in focussing on time zones, the coefficient of $T_{20-30}$ is statistically significant and had a positive impact on dwell time. Therefore, when one-man operation is adopted after the installation of platform doors, it is revealed that relay and excessive dwell time is alleviated for all cases and congested time zone.

\section{Conclusion}

We have introduced an analysis of train operation stability pertaining to the installation of platform doors and/or one-man operation in urban railway networks where trains are running at high density. Train operation stability is clearly understood as it relates to passenger congestion and safety confirmation. When we think of the installation of platform doors, or adopting one-man operation in the future, we have to consider details of passenger congestion, and safety confirmation. 
10 Computers in Railways XV: Railway Engineering Design and Operation

\section{References}

[1] M. Carey: Ex Ante Heuristic Measures of Schedule Reliability, Transportation Research Part B, Vol. 33, pp. 473-494, 1999.

[2] L. Kroon, R. Dekker, G. Maróti: Stochastic Improvement of Cyclic Railway Timetables, Transportation Research Part B: Methodological, Vol. 42, No. 6, 2008.

[3] K. Ushida, S. Makino, N. Tomii: Increasing Robustness of Dense Timetables by Visualization of Train Traffic Record Data and Monte Carlo Simulation, WCRR2011-World Congress on Railway Research, Lille, France, 2011.

[4] T. Graffagnino: Ensuring timetable stability with train traffic data, Computers in Railways XIII, WIT Press, 2012.

[5] A. Yamamura, M. Koresawa, S. Adachi, N. Tomii: How we have succeeded in Regaining Punctuality on the Tokyo Metropolitan Railway Network, WCRR2013-World Congress on Railway Research, Sydney, Australia, 2013.

[6] A. Yamamura, M. Koresawa, S. Adachi, N. Tomii: Taking Effective Delay Reduction Measures Using Delay Elements of Indices on the Tokyo Metropolitan Railways, Computers in Railways XIV, WIT Press, 2014. 